\title{
A Brief Overview of Key Issues in Second Language Writing Teaching and Research
}

\author{
Azim Javadi-Safa* \\ Faculty of Literature and Humanities, Payame Noor University, Rasht, Iran
}

Corresponding author: Azim Javadi-Safa, E-mail: j_teacher2006@yahoo.com

\section{ARTICLE INFO}

Article history

Received: Feburary, 13, 2018

Accepted: March 02, 2018

Published: April 30, 2018

Volume: 6 Issue: 2

Conflicts of interest: None

Funding: None

\begin{abstract}
This paper briefly reviews the literature on writing skill in second language. It commences with a discussion on the importance of writing and its special characteristics. Then, it gives a brief account of the reasons for the weakness of students' writing skill as well as addressing some of the most important topics in L2 writing studies ranging from disciplinary to interdisciplinary to metadisciplinary field of inquiry. In addition, it presents a historical sketch of L2 writing studies, consisting of approaches to teaching writing including behavioristic and contrastive rhetoric as well as discussing approaches to the study of writing including product-oriented, process-oriented, and post-process ones. It also introduces different types of feedback in writing consisting of peer feedback, conferences as feedback, teachers' comments as feedback, and selfmonitoring. Finally, it deals with holistic vs. analytic dichotomy in administration of writing assessment.
\end{abstract}

Key words: Second Language Writing, Behaviorist, Contrastive Rhetoric, Product Oriented, Process Oriented, Post Process, Feedback, Holistic, Analytic

\section{IMPORTANCE OF WRITING SKILL}

Writing is an important communication skill and has an essential role in second language learning process (Chastain, 1988, as cited in Simin \& Tavangar, 2009). This language skill assumed to be of great importance to academic success since it is the commonest assessment measure for academics to evaluate their students, and students' weak writing ability may put their academic success considerably at risk. (Tan, 2011). Therefore, most students, more or less proficient alike, see writing a difficult task that they have to struggle with in order to pass their exams. (Yavuz \& Genc, 1998, as cited in Yavuz-Erkan \& İflazoğlu-Saban, 2011). In addition, due to its active and productive nature, writing in a foreign language is really challenging for students. As Celce-Mercia (1991, as cited in Yavuz-Erkan \& İflazoğlu-Saban, 2011) puts it, accurate and coherent expression of ideas in written form in a foreign or second language is a great accomplishment. Hence, for foreign language learners, writing is an intricate activity that necessitates a confident level of writing conventions, linguistic knowledge, grammar, and vocabulary and needs thinking strategies that let the language learners to express themselves proficiently in the other language (Yavuz-Erkan \& İflazoğlu-Saban, 2011). However, in spite of all the stress laid on writing instruction, learners' writing lingers a regular grumble in both the first and second language educational environments (Tan, 2011).

\section{CHARACTERISTICS OF WRITING}

It seems that a comparison between writing and speech, as two productive language skills, would be beneficial in enlightening the nature of writing. Accordingly, acknowledging the close relationship between writing and speech, Mullany and Stockwell (2010) assumed significant differences between them regarding vocabulary choice, fluency, clause length and complexity, address forms and so forth. They presented several distinctions between speech and writing. First, writing is more monologic than speech. Second, the basic unit of writing is the clause, while for speech the utterance or turn acts as the building stone. Third, writing is more planned whereas speech is more spontaneous. Forth, writing tends to have more standardized and socially accepted forms, while speech is more open to variation in accents. Fifth, writing is more likely to be displaced in time and space (free from context) whereas speech tends to be face-to-face. Finally, writing is visual and relies more on shape and structure, while speech is aural (Mullany \& Stockwell, 2010, pp. 84-85).

Clearly, writing is a cognitive activity; thus, teachers can have a prominent role in assisting students with improving their writing skills through notifying them about the significance of decent writing skills for prosperous progress in their career. They can offer and organize efficient courses in writing that will empower students in acquiring skills and knowledge in helpful writing strategies (Gupta \&Woldemariam, 2011). 
However, since writing is an emotional activity as well as a cognitive one, all aspects of the writing process are affected by its affective factors (McLeod, 1987, as cited in Yavuz-Erkan \& İflazoğlu-Saban, 2011). Some researchers have already investigated the affective variables in writing. For example, Yavuz-Erkan \& İflazoğlu-Saban (2011) studied writing performance of Turkish tertiary-level EFL learners relative to some affective components. As a result, they proposed learners' beliefs about their writing abilities, their apprehension level about writing, and their attitudes towards writing are significant indexes of academic writing performance in EFL students. In another research, Gupta and Woldemariam (2011) examined how motivation and attitudes affect the use of writing strategy of undergraduate students in an EFL setting. They suggested the instrumental motivation towards writing was one of the main factors in developing writing skills of these students. More specifically, their study revealed that high motivation of students leads to high level of confidence, enjoyment, perceived ability, positive attitude towards efficient teaching methods of writing, and to drawing on writing strategies most recurrently.

In addition, one more characteristic of writing, which entails pedagogical implications for language teachers, is that process of writing activity requires writers to progress recursively through prewriting, writing, evaluating, and revising stages (Stapa \& Abdul-Majid, 2009). To emphasize the importance of the prewriting stage, Thompkins (1990, as cited in Stapa \& Abdul-Majid, 2009) pointed that seventy percent of writing time needs to be spent on prewriting. Stapa and Abdul-Majid (2009) investigated the first language use in second language teaching and found a significant development in the writing of students who used their first language to create ideas before writing in second language. Accordingly, they suggested the use of L1 by writing teachers particularly in producing ideas among low-level ESL students.

\section{REASONS FOR THE WEAKNESS OF STUDENTS' WRITING SKILL}

Several factors can account for students' poor writing ability. Some of these reasons are as follows. First reason is due to a reductionist approach to writing, which disregards writing as integrated with other language skills and gives way to more teacher-centered approach. Thus, it overemphasizes correcting surface errors in writing and robs students the chance of selecting their own favorite writing topics (Clippard, 1998, as cited in Tan, 2011). Second reason is attested to writing apprehension or fear of writing, which might be leading from the product approach that only focuses on the product of writing without considering its process (Stapa \& Abdul-Majid, 2009). Unproductive lecture method in teaching writing can be seen as the third reason (Tan, 2011). Forth one, which is particularly noticeable in the EFL/ESL settings, is attributable to large size of writing classes (Warschauer and Ware, 2006, as cited in Tan, 2011). Last but not least reason is the disintegration of print culture and the TV onset, radio, songs, video games, multimedia, computers, and movies (McLuhan and Fiore, 1967, as cited in Tan, 2011).

\section{TOPICS OF L2 WRITING RESEARCH}

Studies on second language writing has been extensively recognized from a disciplinary to an interdisciplinary field of inquiry (for about sixty years), and more recently to a metadisciplinary field of inquiry in s applied linguistics and second language research (Fujieda, 2006; Matsuda et al., 2003). The aim of disciplinary inquiry in second language writing is literacy acquisition and instruction over and above the construction of knowledge about the nature of second language writers and writing (both processes and texts) (Matsuda et al., 2003). On the other hand, due to the interdisciplinary nature of this field, the position of the field is frequently expressed in relation to different other fields, such as foreign language studies, composition studies, bilingual education, Teaching English to Speakers of Other Languages (TESOL), and applied linguistics. Few studies also investigated the correlation between second language writing and TESOL in general (Matsuda et al., 2003). In addition, during the 90s a new field of inquiry named as metadisciplinary inquiry has emerged, which is defined as "inquiry into the nature and the historical development of a field of inquiry as well as its philosophical and methodological orientations" (Matsuda, 1998, as cited in Matsuda et al., 2003). Metadisciplinary inquiry goes one stage backward and studies how the disciplinary inquiry functions; meaning that it highlights queries like "who we are, what we do, and how we do what we do" (Matsuda et al., 2003). Metadisciplinary inquiry in the field of second language writing has taken a lot of various forms that one of its types is the definition of the field -its characteristics, scope, and status (Matsuda et al., 2003).

More specifically speaking of the topics of writing studies, although the main focus of foreign language writing studies has been predominantly on the syntax area, some researchers have investigated other issues such as the pragmatics of metadiscourse. For instance, Simin and Tavangar (2009) found the positive correlation between proficiency in a foreign language and the use of metadiscourse markers. They also pointed the facilitative effect of instruction in this regard.

Furthermore, the topics of second language writing studies encompass diverse issues including literacy development, L2 writing theories, reading-writing connections, ideology and politics, text interactions, research methodology, curriculum design, writing assessment, technology-assisted writing, material design, and so on (Fujieda, 2006). In addition, L2 writing researchers need to consider other factors such as the critical effect of social, cultural, and educational aspects on second language writing investigations (Fujieda, 2006).

As a concise summary, Archibald and Jeffery (2000) categorized the contemporary writing studies into four major domains, including the process of writing, the product of writing, the context of writing, and the teaching of writing. The process of writing generally deals with analysis of composing strategies, modeling cognitive operations, changes in processes over time, and individual differences. The product of writing on the other hand, involves error analysis and contrastive analysis, contrastive rhetoric, and text analysis. The 
context of writing typically investigates social construction, and analysis of the individual's knowledge genre analysis, needs, and motivation. The teaching of writing as the last but not the least area of research into writing investigates learning strategies, learning processes, classroom procedures, development of language proficiency, and assessment. However, these areas of research should not be seen as mutually exclusive but as related and complementary body of research to shaping a comprehensive theory of writing in both L1 and L2 (Archibald \& Jeffery, 2000).

The mounting field of L2 writing still develops pedagogically and theoretically ranging from practical, pedagogical, methodological, and theoretical perspectives as well as to literacy education (Fujieda, 2006). Actually, different extemporized changes - technological, disciplinary, and demographic - and writing L2 researchers' attempt to react to those changes drive the changing intellectual currents in the field of L2 writing (Matsuda et al., 2003).

\section{HISTORICAL OVERVIEW OF THE SECOND LANGUAGE WRITING STUDIES}

A historical overview of L2 writing results in gaining fruitful knowledge of this field of enquiry, developing important learning, and reconstructing uniqueness as a legitimate field of intellectual studies. Hence, the current section gives a chronological account of the prevalent approaches to the teaching writing as well as studying of writing.

\section{Prevalent Approaches to Teaching Writing}

Since writing has always been seen as a daunting task, even for learners who are adept at other language skills, researchers have long looked for appealing and practical ways to improve students' writing skill. Consequently, over the decades, approaches to teaching writing have gone through a myriad of changes (Yavuz-Erkan \& İflazoğlu-Saban, 2011). In this respect, the current section reflects on the way in which the discipline of second language writing has been developed, examines the empirical L2 writing investigations chronologically, and specifically elaborates on two prevalent approaches to teaching writing namely behaviorist and contrastive rhetoric (Fujieda, 2006).

\section{Behaviorist approach}

During the 1950s, there were only few studies, which investigated L2 writing. Teaching English as a second language in the North America were almost restricted to Spanish-speaking learners, while teaching English as a foreign language was not considered seriously as an important issue in this period. Oral rather than written proficiency was given unjustifiable emphasis by the prevalent teaching method during the 1950s (Fujieda, 2006).

In the 1960s, along with the entrance of substantial body of foreign students aspiring to study in higher education in the U.S., first language writing teachers noticed considerable divergences in writing between first and second language learners. Perceiving these dissimilarities resulted in controversial division of writing pedagogy into L1 and L2 issues, which in its own turn leads to establishing the "disciplinary division of labor" between L2 studies and composition (Matsuda et al., 2003). Then, compensating for the negligence of teaching writing in English to ESL learners in the past, ESL writing turned out to be a noteworthy subfield of L2research (Fujieda, 2006). During this decade, writing instruction for L2 learners, following a behaviorist approach, focused on the L2 structure via a prescriptive controlled practice as in the Audiolingual Method which was the dominant mode of instruction during the sixties (Btoosh \& Taweel, 2011). As a result, writing was restricted to drills such as fill-ins, substitutions, transformations, and completion. It used to strengthen or examine the perfect application of grammatical rules. This kind of focus neglected the enormous complexity of writing (Derakhshan, 1996).

\section{Contrastive rhetoric approach}

Afterwards, writing instructors, encompassing the structural exercises of paragraphs, recognized the necessity of adopting progressive practices of writing beyond the sentence level. Such a practical application of syntactic structure to paragraph formations resulted in the appearance of Contrastive Rhetoric (CR) by Kaplan (1966) who stresses the fundamental notion of cultural differences and variations, which is consecutively, reflected in students' writing. This approach also concentrates on the expectations of readers outside the classroom. The reader is considered as the representative of a large discourse community, and rhetorical forms, rather than grammatical forms, are regarded as paradigms (Derakhshan, 1996).

Kaplan (1966), after investigating 700 L2 students' compositions, claimed that native language and cultural impact cause idiosyncratic rhetorical patterns of ESL writing. He proposed a diagram of five special linguistic characteristics (English, Oriental, Semitic, Russian, and Romance) that he called "cultural thought patterns." Based on his contrastive rhetoric research, English-speaking writers utilized a linear structure with specific details to maintain the theme. In contrary to English speakers, he reported distinctively on the rhetorical models of other languages. Arabic writers, in their compositions, tapped into a lot of coordination words in comparison to English learners. French and Spanish learners digressed from the theme with unrelated descriptions. Asian students demonstrated an illogical structure, encircling the topic. Empirical investigations beyond $\mathrm{CR}$ characteristics (CR in addition to syntactic explorations) were carried out across different languages after Kaplan's contrastive rhetoric research (Fujieda, 2006).

As an example, Kobayashi (1985, as cited in Fujieda, 2006) investigated the variations of writing organizations between English and Japanese students. Her study demonstrated that English-speaking students employed general-specific patterns. They cited a general statement at the beginning and went on with details while Japanese writers utilized specific-general cases in which they initially mentioned specifics that reflected a general description. In addition, Hinds (1983, 1984, as cited in Fujieda, 2006) studied the argumenta- 
tive writing structures between English and Japanese. The English writers, as in Kaplan's rhetorical model, benefited the linear and deductive pattern while the Japanese students used the Japanese rhetorical model.

Although, according to Scollon (1997), contrastive rhetoric has originated from earlier studies on error analysis and on the weak version of the Sapir-Whorf Hypothesis which postulates a close interrelationship between language and culture, Ying (2000, as cited in Btoosh \& Taweel, 2011) argued that Hymes' (1962, p. 964) ethnography of communication approach is regarded an influential chronological predecessor for contrastive rhetoric.

Hymes (1966, as cited in Scollon, 1997) suggested that the Whorfian hypothesis ought to be tested again, and claimed that before being able to make any statement about the interrelationship between culture and language, we should have examined the function of culture and language in the person's life. In order to argue that language learners write with a particular structure due to some other language they speak or, more indirectly, due to a particular culture of which they are members, we should have developed a clearer portrait of how that language, culture, and group are assimilated (Scollon, 1997).

Although Kaplan's (1966) pioneering study on CR had a strong influence on second language writing research, his investigation caused much debate too. A few specialists criticized the deterministic rhetorical model for continuing a negative complex towards the writing patterns of L2 learners (e.g. Zamel, 1997; Kubota, 1997, 1999; Leki, 1991; Ferris and Hedgcock, 2005, as cited in Fujieda, 2006), and "privileging the writing of native English speakers, as well as for denigrating linguistic and cultural differences in writing among different languages" (Connor, 1996). In other words, Kaplan's diagram particularly generalized L2 writing characteristics. After Kaplan's study, the subject of contrastive rhetoric still sparks theoretical and educational perspectives with different methods. Specifically, several composition investigators argued for a critical writing pedagogy to adjust L2 learners to the target discourse community even when applying contrastive rhetoric research to EFL/ESL writing classrooms drawing remarkable criticism from writing researchers (Ramanathan\& Atkinson, 1998; Kubota, 1999; Connor, 2001, as cited in Fujieda, 2006). However, Ramanathan and Atkinson (1998, as cited in Fujieda, 2006) warned that teaching EFL/ESL students writing in English to follow the English rhetorical pattern overtly could cause an ideological problem, and disgrace the values of the students' social as well as cultural individuality.

Contrastive rhetoric analysis had a serious impact on second language writing studies. It signified the nature of L2 writers' texts, and underlined influence of the writers' cultural contexts on the texts comprising grammatical and lexical characteristics (Fujieda, 2006). Contemporary studies on contrastive rhetoric are redefined with the innovative prospects of contrastive rhetoric pedagogy. In a more recent definition of contrastive rhetoric, Connor (1996) describes it as "an area of research in second language acquisition that identifies problems in composition faced by second language writers, and, by referring to the rhetorical strategies of the first language, attempts to explain them" (p. 5).She expounds on how other fields has benefited from and contributed to contrastive rhetoric. The three main viewpoints on the writing process derived from rhetoric and composition theory: expressionist, cognitive, and social constructivist. These approaches offer the structure for analyzing the product and process of writing in a second language. Based on Connor (1996), contrastive rhetoric has heavily drawn on methodologies of text linguistics in analyzing such text attributes as coherence, narrative structure, or morphosyntactic features. The contrastive rhetoric researchupdated by text linguistics has enlightened dissimilarities between first and second language texts plus among texts of various genres. Connor (2002, as cited in Btoosh \& Taweel, 2011) classified the studies on contrastive rhetoric over the last three decades into four major categories, including studies of writing as cultural and educational activity, contrastive text linguistic studies, genre-specific investigations, and classroom-based contrastive studies. Regarding the applications of contrastive rhetoric for research and pedagogy, she views contrastive rhetoric as improving learners' writing proficiency as well as enriching their culture, especially those in EFL contexts, In her point of view "contrastive rhetoric is an excellent resource for advanced- or college-level ESL/EFL writing teachers, both for gaining understanding in culturally different writing patterns and for designing writing programs in light of genre, cultural, or rhetorical concerns" (Connor, 1996). As for future implications, Connor (2001, as cited in Fujieda, 2006) states that "future contrastive rhetoric research should be sensitive to the view that writers be seen not as belonging to separate, identifiable cultural groups but as individuals in groups that are undergoing continuous change" (p. 76).

In conclusion, although both behaviorist and contrastive rhetoric approaches to teaching writing emerged in chronological order as a critical reaction to a previous one, they are not mutually exclusive. Currently these approaches are all widely applied and have somehow made teaching writing a demanding task; since, as Raimes (1991, as cited in Derakhshan, 1996) puts it, today, teachers have to take account of several different approaches, "their underlying assumptions, and the practice that each philosophy generates" (p. 412).

\section{Approaches to the Study of Writing}

Traditionally, there are two prevalent approaches to the study of writing: the product-orientated approach and the process-orientated approach (Arefi, 1997). According to Blackmore-Squires (2010), the distinction between the aforementioned approaches mostly is that the process approach deals with the way through which reaches the finished product. In contrast, the product approach deals with the final product and its evaluation. The two approaches were developed concurrently as reaction to each other. It is also worth mentioning that even the process approach pays attention to the product or the final piece of work. However, in this approach more emphasis is laid on how to get there and skills development along the way (Blackmore-Squires, 2010). However, more recently, a new stage of development 
in L2 writing, namely post-process has been commenced, which pays more attention to social dimensions of the field (Fujieda, 2006) and consequently, dramatically increased popularity of collaborative writing (Godwin-Jones, 2018).

Study of the written product, according to Arefi (1997), has focused on language and linguistic structures in students' writing (e.g. Hunt, 1977 in using the T-Unit; Mehan, 1979 in using syntactic complexity; Vann, 1980 in using syntactic maturity) as well as more general characteristics such as communicative effectiveness and other traits proposed by rhetorical theories (e.g. Carlisle, 1986; Lloyd-Jones,1977). Examining the product of writing, Vann (1980, as cited in Arefi, 1997) suggested syntactic length as a measure of writing proficiency. In another study, Cooper (1983, as cited in Arefi, 1997), suggested that in good writing the sentences are needed be related to each other. This connection is significant since it "provides the structural and semantic relations between words across sentences, from the link between specific words across sentences to abstract, global thematic and structural patterns" (Arefi, 1997).

In the writing process, according to Flower and Hayes (1981), three elements interact with each other to produce a composition. First, there is the task environment that consists of everything outside the writer's body, such as audience and written text itself. Next, there is the writer's knowledge of the topic as well as the writer's knowledge of writing rhetorical problems, plans, genre, and conventions. It is noteworthy the writer can elicit from memory during the composing process. The final element is the writing processes that are the major thinking processes that writers employ in complicated ways during their writing.

Considering this final element and based on protocol ${ }^{1}$ analysis Hayes and Flower (1980) put forward a process approach theory to the study of process of writing in the early 80 's. According to this theory, it was postulated that the writer's long-term memory and the task affects writing. Process approach theory has three phases encompassing planning, translating, and reviewing. Planning is producing content, organizing it, and determining goals and procedures for writing. Prior to the beginning of writing, the writer requires a form of mental activity, and therefore, planning acts as a thinking activity. Translating is expression of the content of planning in a composition. Hereby, a writer is attempting to produce and develop her or his idea in a meaningful statement. When translating, sometimes a writer has to go back to planning for the act of translating. The act of reviewing refers to the evaluation of what has been written and planned. Sometimes due to the unsatisfactory result of this evaluation, the writer needs to revise a composition (Arefi, 1997). The process oriented approach according to Connor (1987) emphasizes processes of writing; instructs strategies for discovery and invention; takes account of purpose, audience, and the context of writing; stresses recursiveness - involving the writers to read back in order to write forward - in the writing process; and differentiates goals and mode of discourse (e.g. expository, expressive, persuasive, classification narration, evaluation, and description). It is also worth noting that more recently, (Johari, 2018) showed that the amalgamation of process writing and task-based approach significantly improve second language learners' academic writing.
However, Reid (2001, as cited in Fujieda, 2006) considers the controversy between the process and product approach in ESL/EFL contexts as "a false dichotomy," and states that many L2 writers were directed by "process writing strategies to achieve effective written communication (product), with differences occurring in emphasis" (p. 29).

Moreover, although process approach theory has been a commonly acknowledged model of the writing process, it has caused criticism since it is based on studies with L1 writers, and consequently, input from long-term memory of the L2 writer is not the main concern within the process (Blackmore-Squires, 2010).

In the early nineties, writing scholars noticed the essential difference between the product and process approach. Process-oriented research originate the issues of institution which stress a specific aim such as EAP (English for Academic Purposes) and ESP (English for Specific Purposes) to value the audience in writing rather than the writer (Fujiada, 2006). After 2000, an original process inquiry into more social issues, the post-process, has emerged in the L2 writing context. Atkinson (2003, as cited in Fujieda, 2006) proposed that the post-process, which previously controlled students' process feature as a cognitive process, ought to be disregarded. Subsequently, he mentioned that in the post-process "we seek to highlight the rich, multifocal nature of the field," and "go beyond now-traditional views of L2 writing research and teaching."

In summary, the product oriented traditional approach focused on expository writing; made style the most significant component in writing, and postulated that the writing process is linear, specified by writers before they begin to write (Kaplan,1966). On the other hand, the process oriented approach, emphasizes the activity (process) of writing, investigates the individual writer's approaches to writing, and highlights the way in which students managed to follow the process through writing.

Today, process inquiry in L2 writing has entered the period of "post-process era," which puts in more social aspects to writers, and ignores cognitive science to exceed prevalent perspectives in L2 writing studies and teaching (Fujieda, 2006). In other words, Post-process approach considers writing as a collaborative and social act rather than a certain technique that can be codified and taught to individual learners (Kalan, 2014). More specifically, written texts need to be viewed as products of a complicated web of social interactions, cultural practices, discursive conventions, and power differentials (Howard, 2001; Casanave, 2003; Atkinson, 2003, as cited in Kalan, 2014). Moreover, Kalan (2014) reviewing the relevant literature regarding post-process theory since 1990, presents seven focal arguments in a more comprehensive definition as follows:

1. Writing cannot be reduced to a single codified process to be taught.

2. Essayist literacy and the rhetoric of assertion should be challenged in order to broaden genre possibilities.

3. Writing should liberate students' agencies.

4. Writing is not an individual activity taught through a simple classroom pedagogy. 
5. Teachers need to move beyond the classroom as the only rhetorical situation and their role as the possessor of the techne $e^{2}$ of writing.

6. Written texts should be regarded as products of a complicated web of cultural practices, social interactions, power differentials, and discursive conventions.

7. Teaching writing is basically teaching rhetorical sensitivity and hermeneutic guessing through a large number of literate activities.

Most definitions of post-process theory stipulates that post-process does not try to reject process theory but tries to broaden its prospects through critical re-readings of it (Couture, 1999, p. 31; Atkinson, 2003; Foster, 1999, p. 149, as cited in Kalan, 2014) and regards it as the recognition of the multiplicity of second language writing pedagogies and theories (Matsuda, 2003).

Although a few studies (e.g. Chow, 2007; Ahn, 2002, as cited in Fazilatfar et al., 2016) showed an enhancing effect of post-process or genre approach regarding learners' overall proficiency, awareness of conceptual writing strategies, willingness in applying the strategies and their attitudes toward writing activities, Hashemnezhad and Hashemnezhad (2012) investigating EFL students' writing ability in terms of three writing approaches of product, process, and post-process, concluded that post- process approach didn't have any significant primacy over process approach, but they both have substantial superiority over product approach. However, more recently, Rusinovci (2015) proposed an integrated approach to the teaching of writing through combining the strength of the genre and process approaches for utilization in writing courses. He claims such an approach presents several benefits including more focused use of text models without having to exclude components of other approaches. Furthermore, regarding writing evaluation in post-process approach, Sukandi (2016) claims that "the quality of the students writings needs to be seen from the process itself and how the students come to the understanding that writing is a social act and a medium of individual expression over academic realm." He, investigating self-evaluation essays as the post-process pedagogy in teaching writing, concludes that students have their inclination to see our class through different ways, and consequently, they will firstly see us as the thing they see all the time, then the process of what they learn become the aspect they see, which can be seen as further confirmation on the social nature writing evaluation. It is also worth mentioning that with the advent of new technological advances in writing pedagogy, Herron (2017) studied the integration of mobile device into the composition classroom in post(e)-pedagogy1 which he believes brings new opportunities and frameworks to analyze and create in composition studies. He states that a key element of post(e)-pedagogy is the relinquishing of master and a personalized approach to pedagogy for both the teacher and student which agrees well with the notion of a mobile composition and puts the mastery in students' hands. At last, it should be noted that L2 writing is still a developing field in applied linguistics and second language studies.

\section{FEEDBACK IN WRITING}

Feedback is an important and essential issue in writing courses especially in process approach since this approach recommends the effectiveness of intervention at all stages of writing (McDonough \& Shaw, 2003, p. 166). According to Keh (1990) it is defined as "input from a reader to a writer with the effect of providing information to the writer for revision" (p. 294). He classified it into three major types of peer feedback, conferences as feedback, and teachers' comments as feedback.

In Peer feedback the students, generally using the questions provided by their teacher, examine their peers' written work and give feedback to each other. According to Bartels (2003) the terms "peer review, peer editing, peer evaluation, peer response, and peer critiquing" are interchangeably used for this type of feedback. Also, Byrd (2003) introduced different techniques of peer feedback including "classic peer editing, booklet editing, silent editing, slice and dice, post teacher check, colored pencils/highlighters, computer editing, and reader-response editing."

Conference as feedback is divided into student-teacher conference and group conference. The former, based on White and Arndt (1991), is carried out on a face-to-face basis and teachers are able to discuss the problems with their students. In the latter, according to Keh (1990), some groups read aloud sections of their own compositions for feedback; other students read aloud their partner's composition with comments about where they think the composition seems wrong, and suggest how to improve it.

As Keh (1990) put it, in teachers' comment as feedback, teachers may have different roles. First, they can comment as readers interacting with a student - i.e. responding to the composition with phrases such as "good point" or "I agree". Second, still holding the role of a reader, they can draw student's attention to specific point of confusion or to strategies for revision such as choices of problem solving, options, or an example. Finally, adopting the role of a grammarian, they can provide reference to grammatical mistakes along with the reasons for the unsuitability of those mistakes. Sheppard (1992) also, investigating the efficacy of two kinds of responding to students' compositions including "holistic feedback on meaning" and "discrete-item attention to form", showed the superiority of the former in increasing students' awareness of sentence boundaries and grammatical accuracy.

It is also worth noting that all these three types of feedback can be provided through three different methods including minimal marking, taped commentary/audio taped feedback, and online peer review/computer-based commentary (Hyland, 1990; Swaffer et al., 1998).

Finally, self-monitoring is another technique for providing feedback that is also useful in developing learners' autonomy. Through this technique learners make notes in their drafts with questions and comments on their problems before submitting their papers and then teachers give feedback on them (Charles, 1990). 


\section{WRITING ASSESSMENT}

There are two types of writing administrations: analytical and holistic (impressionistic). In analytic writing, rather than given a single score, assesses compositions based on several criteria or writing features. Consequently, "writing samples may be rated on such features as content, organization, cohesion, register, vocabulary, grammar, or mechanics" (Weigle, 2002, p. 114). In Contrast, on a holistic scale, a single mark is given to the whole essay. The underlying assumption is that in holistic approach raters will draw on set of marking scales to direct them in scoring the compositions (Weigle, 2002, p. 72).

The analytic approach on L2 writing has provided a lot of materials for writing studies. The virtues of the analytic rating are because of the detailed direction that is presented to the writing judges, and the rich information as criteria that is supplied on particular strengths and weaknesses of the test-takers' performance (Chuang, 2009). Such information generates valuable diagnostic input about testees' writing skills, which is the major advantage of analytic approach (Vaughan, 1991; Gamaroff, 2000, as cited in Aryadoust, 2010). Consequently, Researchers have long constructed analytic writing descriptors, each including several criteria to measure subskills such as vocabulary, grammar, content, and organization. Weir's (1990) long list with seven subcategories is one of the most comprehensive ones to gauge writing sub-skills, and an instance of a shorter and probably more practical list is Astika's (1993) three proposed rating benchmarks. Another example is the present rating scale in the IELTS writing test that is founded on a recent exposition of writing assessment and performance (Shaw \& Falvey, 2008). Aryadoust (2010) reports examples of some crafting skills in analytic assessing of writing, including overall effectiveness, fluency, intelligibility, comprehension, resources, and appropriateness, which had an impact on writing performance the most (McNamara, 1996); relevance and adequacy of content, compositional organization, cohesion, adequacy of vocabulary, grammar, punctuation, and spelling (Weir, 1990); control over structure, organization of materials, vocabulary use, and writing quantity (Mullen, 1977); and sentence structure, vocabulary, and grammar (Daiker, Kerek, \& Morenberg, 1978); content, language use, organizing ideas, lexis, and mechanics (spelling and punctuations) (Jacobs et al., 1981).The effectiveness of some of these frameworks has been justified; for instance, Brown and Baily (1984) examined Jacobs et al.'s (1981) framework and found that drawing on an analytic framework of grammar, organization, style, logical development of ideas, and mechanics of writing, is a significantly justifiable scheme in evaluating writing performance.

The holistic approach toward writing and its assessment has also been studied extensively. A holistic evaluation considers an overall impression of the writer's performance. In other words, the raters react to the written production as a whole, and one mark is assigned to a composition. As Chuang (2009) puts it, "the holistic scales are more practical for decision-making since the raters only marked one score: the flexibly allowed many different combinations of strengths and weakness within a level." From a judge's point of view, "holistic rating scales make [scoring easier and quicker] be- cause there is less to read and remember than in a complex grid with many criteria" (Luoma, 2004, as cited in Chuang, 2009). It is postulated that a high portion of variability in holistic writing scores is resulted from four subclasses of grammar competence, that is, sentential connectors, length, errors, and relativization/subordination (Homburg, 1984, as cited in Aryadoust, 2010). Several researchers especially those studying high-stake tests are in favor of the holistic approach. For instance, among IELTS writing investigators, Mickan and Slater (2003) proposed that a more holistic approach to assessing writing would be more sensible than a very meticulous, analytical approach, and claimed that "Highlighting vocabulary and sentence structure attracts separate attention to discrete elements of a text rather than to the discourse as a whole" (p. 86). Consequently, they suggested a more impressionistic approach to assessing writing rather than the analytic one. In another research, Obeid (2017), investigating the attitudes and perception of EFL learners toward second language writing evaluation, reports the students' tendency toward a more holistic approach. However, it is also worth noting that some recent research into writing assumes that due to similarities between writing sub-skills, having composite sub-skills where two or more categories are accommodated into a single rubric is possible (Aryadoust, 2010).

Since during the last few decades the focus of L2 writing shifted from linguistic accuracy to communication of ideas, the writing assessment, regardless of analytic or holistic scales, pays more attention to the content (Ruegg \& Sugiyama, 2010). Quantity of main ideas, the logical connection between the main ideas and the thesis statement, the use of examples to support the main ideas, and the level of development of the main ideas are amongst the factors that are most commonly drawn on by raters for evaluating the content of writing (Ruegg \& Sugiyama, 2010).However, in a recent study, Ruegg and Sugiyama (2010) suggested the organization score in first place and the essay length in the second place as the main predictors of content score.

In conclusion, as Chuang (2009) mentioned, it is the purposes of the assessment and the availability of existing instruments that verify the appropriacy of a rating scale. Rating schemes may describe different degrees of competence along a scale or may indicate the presence or absence of a trait. Furthermore, choosing testing procedures should entail coming across the unsurpassed feasible amalgamation of the qualities (validity, reliability, etc.) and determining which qualities were most pertinent in a specified context (Weigle, 2002, as cited in Chuang, 2009).

\section{CONCLUSION}

The prominence of writing ability and its serious position in representing students' learning degree is indisputable in second language teaching and research. In effect, writing is considered as a difficult task, even for native speakers though it is much more intimidating for non-natives, especially EFL learners. The special characteristics of writing which give it such importance as well as some of the factors making writing one the most difficult language skills to learn has been enumerated above. Generally, writing research topics in second language 
studies range from disciplinary to interdisciplinary and finally to metadisciplinary field of inquiry. In addition, while behavioristic and contrastive rhetoric are considered as the two main approaches to teaching writing, we can name the product-oriented, the process-oriented, and the post-process approaches as the prevalent ones to the study of writing. Finally, the administration of writing assessment is categorized into analytical and impressionistic (holistic) approaches which have long been drawn on by language teachers and researchers.

\section{END NOTES}

1 . Hayes and Flowers in Greg and Steinberg defines a protocol as;

"A description of the activities ordered in time, that a subject engages in whilst performing a task"(1980, p. 4).

2 "Technêis conceived as techniques for situating bodies in contexts" (Hawk, 2004).

3 Postpedagogy is a more general discussion of the need to abandon prescriptive pedagogy while post(e)-pedagogy is Ulmer's discussion of such matters with the focus on the electronic(Herron, 2017).

\section{REFERENCES}

Ahn, H. (2012). Teaching writing skills based on a genre approach to L2 primary school students: An action research. English Language Teaching, 5(2), 2.

Archibald, A. \& Jeffery, G. (2000). Second language acquisition and writing: A multi-disciplinary approach. Learning and Instruction, 10, 1-11. Retrieved October 20, 2011 from www.elsevier.com/locate/learninstruc.

Arefi, M. (1997). The relationship between first and second language writing skills for Iranian students in Sydney: An application of the Interdependence Hypothesis. (Doctoral Dissertation).Nepean: University of Western Sydney. Retrieved January 18, 2011 from http://www. Irandoc.ac.ir

Aryadoust, V. (2010). Investigating writing sub-skills in testing English as a foreign language: A structural equation modeling study. The Electronic Journal for English as a Second Language, 13(4), A-9. Retrieved January 22, 2012 from www.tesl-ej.org/pdf/ej52/a9.pdf

Astika, G. G. (1993). Analytical assessment of foreign students' writing. RELC Journal, 24(1), 371-389.

Atkinson, D. (2003). L2 writing in the post-process era: Introduction. Journal of Second Language Writing, 12(1), 3-15. doi: 10.1016/S1060-3743(02)00123-6

Bartels, N. (2003). Written peer response in L2 writing. English Teaching Forum, 41(1), 34-37.

Blackmore-Squires, S. (2010). An investigation into the use of blog as a tool to improve writing in the second language classroom. (MA dissertation). Submitted to the University of Manchester. Retrieved August 10, 2011 from http://www.asian-efl-journal.com/Thesis/ Thesis-Squires.pdf

Brown, J. D., \& Baily, K. M. (1984). A categorical instrument for scoring second language writing skills. Language Learning, 34(4), 21-42.
Btoosh, M. A. \& Taweel, A. (2011). Contrastive Rhetoric: Inflation, verbal voices and polyphonic visibility in learners and native speakers' academic writing. Asian EFL Journal, 13(3), 205-228. Retrieved October 15, 2011 from http://www.asian-efl-journal.com/PDF/September-2011.pdf

Byrd, D. R. (2003). Practical tips for implementing peer editing tasks in the foreign language classroom. Foreign Language Annals 36, 434-439.

Carlisle, R. S. (1986). The writing of Anglo and Hispanic fourth and sixth graders in regular, submersion, and bilingual programs. (Unpublished doctoral dissertation). University of Illinois, Urbana-Champaign.

Casanave, C. P. (2003). Looking ahead to more sociopolitically-oriented case study research in L2 writing scholarship (but should it be called "post-process"?). Journal of Second Language Writing, 12(1), 85-102. doi: 10.1016/ S1060-3743(03)00002-X

Celce-Murcia, M. (1991). Language teaching methodology. London: Prentice Hall.

Charles, M. (1990). Responding to problems in written English using a student self-monitoring technique. ELT Journal, 44(4), 286-293.Chastain, K. (1988). Developing second language skills: Theory and practice. New York: Harcourt Brace Jovanovich.

Chow, T. V. F. (2007). The Effects of the Process-Genre Approach to Writing Instruction on the Essays of Form Six ESL Students in a Malaysian Secondary School. Unpublished $\mathrm{Ph}$. D. dissertation. Universiti Sains Malaysia.

Chuang, Y. (2009). Foreign language speaking assessment: Taiwanese college English teachers' scoring performance in the holistic and analytic rating methods. Asian EFL Journal, 11(1), 150-173. Retrieved October 16, 2011 from http://www.asian-efl-journal.com/ March_09_yyc.php

Clippard, D. (1998, Fall/Winter). Efficacy of Writers' Workshop for students with significant writing deficits. Journal of Research in Childhood Education, 13(1).

Connor, U. (1987). Research frontiers in writing analysis. TESOL Quarterly, 21(4), 677-696. Retrieved April 28, 2012 from http://www.jstor.org/stable/3586989.

Connor, U. (1996). Contrastive rhetoric: Cross-cultural aspects of second-language writing. New York, NY: Cambridge University Press.

Connor, U. (2001). Contrastive Rhetoric Redefined. Contrastive Rhetoric Revisited and Redefined. Ed., Clayann, Panetta, G. Mahwah: Lawrence Erlbaum, 75-78.

Connor, U. (2002). New directions in contrastive rhetoric. TESOL Quarterly, 36(4), 493-510.

Cooper, C. R. (1983). Procedures for describing written texts. In P. Mosenthal., L. Tamor., \&S. A. Walmsley (Eds.), Research on writing principles and methods (pp. 287-313) New York, London: Longman.

Couture, B. (1999). Modeling and emulating: Rethinking agency in the writing process. In T. Kent (Ed.), Post-process theory: Beyond the writing process paradigm (pp. 30-48). Carbondale, IL: Southern Illinois University Press. 
Derakhshan, K. (1996). Effects of first language on second language writing - A preliminary contrastive rhetoric study of Farsi \& English. Unpublished MA dissertation. Tehran: Allameh Tabatabai University. Retrieved March 15, 2011 from http://www.irandoc.ac.ir

Fazilatfar, A. M., Ilun, M. \&Chenari, Z. (2017). Impact of Skill-Based Communicative Approach on Writing Skill of EFL Learners. International Journal of Scientific Study, 5(4), 55-66. Retrieved March 6, 2018 from https://www.ijss-sn.com/uploads/2/0/1/5/20153321/ ijss-iran_jul_oa09_-_2017.pdf

Ferris, D. \& Hedgcock, S. J. (2005). Teaching ESL Composition: Purpose, Process, and Practice, $2^{\text {nd }}$ ed. Mahwah: Lawrence Erlbaum.

Flower, L. \& Hayes, J. R. (1981). A cognition process theory of writing. College Composition and Communication, 35, 365-387.

Foster, D. (1999). The challenge of contingency: Process and the turn to the social in composition. In T. Kent (Ed.), Post-process theory: Beyond the writing process paradigm (pp. 149-162). Carbondale, IL: Southern Illinois University Press.

Fujieda, Y. (2006). A brief historical sketch of second language writing studies: A retrospective. Kyoai Gakuen Maebashi Kokusai Daigaku Ronsyuu, 6, 59-72. Retrieved September 25, 2011 from www.kyoai.ac.jp/college/ronshuu/no-06/fujieda.pdf

Gamaroff, R. (2000). Rater reliability in language assessment: The bug of all bears. System, 28(1), 31-53.

Godwin-Jones, R. (2018). Second language writing online: An update. Language Learning \& Technology, 22(1), 1-15. Retrieved March, 28, 2018 from https://dx.doi. org/10125/44574

Gupta, D. \& Woldemariam, G. S. (2011). The influence of motivation and attitude on writing strategy use of undergraduate EFL students: Quantitative and qualitative perspectives. Asian EFL Journal, 13(2), 34-89. Retrieved September 5, 2011 from http://www.asian-efl-journal. com/PDF/June_2011.pdf

Hashemnezhad, H. \& Hashemnezhad, N. (2012). A Comparative Study of Product, Process, and Post-process Approaches in Iranian EFL Students' Writing Skill. Journal of Language Teaching and Research, 3(4), 722-729. Retrieved March 6, 2018 from http://www.academypublication.com/issues/past/jltr/vol03/04/18.pdf

Hawk, B. (2004). Toward a Post-Technê - Or, Inventing Pedagogies for Professional Writing. Technical Communication Quarterly, 13(4), 371-392. Retrieved March 5, 2018 from www.ericandjulia.org/5400/docs/hawk post_techne.pdf.

Hayes, J. R. \& Flower, L. (1980). Identifying the organization of writing Processes. In Gregg, L. W. \& Steinberg, E. R. (Eds.), Cognitive Processes in Writing, Erlbaum, Hillsdale.

Herron, J. P. (2017). Moving Composition: Writing in a Mobile World. All Dissertations. 1986. Retrieved March 5, 2018 from http://tigerprints.clemson.edu/all_dissertations/1986.

Hinds, J. (1983). Contrastive Rhetoric: Japanese and English. Text 3 183-195.
Hinds, J. (1984). Retention of Information Using a Japanese Style of Presentation. Studies in Language 8, 45-69.

Homburg, T. J. (1984). Holistic evaluation of ESL composition: Can it be validated objectively? TESOL Quarterly, 18, 87-107.

Howard, R. M. (2001). Collaborative pedagogy. In G. Tate, A. Rupiper, \& K. Schick (Eds.), A guide to composition pedagogies (pp. 54-70). New York, NY: Oxford University Press.

Hunt, K. W. (1977). Early blooming and late blooming syntactic structure. In C.R. Cooper and L. Odell (Eds.), Evaluating writing: Describing, measuring, judging. Urbana, Ill.: National Council of Teachers of English.

Hyland, K. (1990). Providing productive feedback. ELT Journal, 44(4), 279-285.Hymes, D. (1962). The Ethnography of Speaking. In T. Gladwin \& W. C. Sturtevant (Eds.), Anthropology and Human Behavior (pp. 13-53). Washington, DC: Anthropology Society of Washington.

Hymes, D. (1966). On 'Anthropological Linguistics' and Congeners. American Linguistic Anthropology 68, 143153.

Jacobs, H. L., Zinkgarf, S. A., Wormuth, D. R., Hartfiel, V. F., \& Hughey, J.B. (1981). Testing ESL composition: A practical approach. Rowley, MA: Newbery House.

Johari, S. K. (2018). The Effects of Task-Based Process Writing Approach on the Academic Writing Skills among Second Language Tertiary Learners. Journal of ELT Research, 3 (1), 1-20. Retrieved March 28, 2018 from https://journal.uhamka.ac.id/index.php/jer/article/ view/1064/400

Kalan, A. (2014). A Practice-Oriented Definition of Post-Process Second Language Writing Theory. TESL Canada Journal, 32(1), 1-18. Retrieved March 2, 2018 from http://www.teslcanadajournal.ca/index.php/tesl/article/ view/1196/1016.

Kaplan, R. B. (1966). Cultural thought patterns in intercultural education. Language Learning, 16,1-20.

Keh, C. L. (1990). Feedback in the writing process: a model and methods for implementation. ELT Journal, 44(4), 294-304. Retrieved April 3, 2018 from http://dx.doi. org/10.1093/elt/44.4.294

Kobayashi, H. (1985). Rhetorical Patterns in English and Japanese. (Doctoral dissertation). Retrieved March 25, 2018 fromhttps://goo.gl/vP2ncY

Kubota, R. (1997). A Reevaluation of the Uniqueness of Japanese Written Discourse. Written Communication, 14, 460-480.

Kubota, R. (1999). Japanese Culture Constructed by Discourses: Implications for Applied Linguistics Research and ELT. TESOL Quarterly33, 9-35.

Leki, I. (1991). Twenty-Five Years of Contrastive Rhetoric: Text Analysis and Writing Pedagogies. TESOL Quarterly 25, 123-143.

Lloyd-Jones, R. (1977). Primary trait scoring. In C.R. Cooper and L. Odell (Eds.), Evaluating writing: Describing, measuring, judging. Urbana,Ill.: National Council of Teachers of English. 
Luoma, S. (2004). Assessing speaking. Cambridge: Cambridge University Press.

Mangubhai, F. (2005). What can EFL Teachers Learn from Immersion Language Teaching? The Asian EFL Journal, 7(4), 203-212.

Matsuda, P. K. (1998). Situating ESL writing in a cross-disciplinary context. Written Communication, 15, 99-121.

Matsuda, P. K. (2003). Process and post-process: A Discursive History. Journal of Second Language Writing, 12(1). Retrieved March 5, 2018 from https://goo.gl/2q6opb

Matsuda, P. K., Canagarajah, A. S., Harklau, L., Hyland, K. \&Warschauer, M. (2003). Changing Currents in Second Language Writing Research: A colloquium. Journal of Second Language Writing, 12, 151-179.

McDonough, J. \& Shaw, C. (2003). Materials and Methods in ELT. Oxford: Blackwell Publishing.

McLeod, S. (1987). Some thoughts about feelings: The affective domain and the writing process. College Composition and Communication, 38(4), 426-435.

McLuhan, M., \& Fiore, Q. (1967). The medium is the message. Harmondsworth: Penguin.

McNamara, T. F. (1996). Measuring second language performance. NY: Longman. Daiker, D., Kerek, A., \& Morenberg, M. (1978). Sentence combining and syntactic maturity in freshman English. College Composition and Communication, 19(1), 36- 41.

Mehan, H. (1979). Learning lessons: Social organization in the classroom. Cambridge, MA: Harvard University Press.

Mickan, P. \& Slater, S. (2003). Text analysis and the assessment of academic writing. Research Report No. 4, IELTS Australia.

Mullany, L. \& Stockwell, P. (2010). Introducing English language: A Resource book for students. New York: Routledge.

Mullen, K. A. (1977). Using rater judgments in the evaluation of writing proficiency for non - native speakers of English. In H. D. Brown, C. A. Yorio, \& R. H. Crymes (Eds.), Teaching and learning English as a second language: Trends in research and practice (pp. 309 -332). Washington, DC: TESOL.

Obeid, R. (2017). Second Language Writing and Assessment: Voices from Within the Saudi EFL Context. English Language Teaching, 10(6), 174-181. Retrieved March 27, 2018 from http://www.ccsenet.org/journal/ index.php/elt/article/view/68492/37150

Raims, A. (1991). Out of the Woods: Emerging Traditions in the Teaching of Writing. TESOL Quarterly 25(3), $407-$ 430 .

Ramanathan, V. \& Atkinson, D. (1998). Individualism, Academic Writing, and ESL Writers. Journal of Second Language Writing 8, 45-75.

Reid, J. (2001). Writing. The Cambridge Guide to Teaching English to Speakers of Other Languages. R, Carter, and D. Nunan (pp. 60-65). Cambridge: Cambridge UP.

Ruegg, R \& Sugiyama, Y. (2010). Do analytic measures of content predict scores assigned for content in timed writing? Melbourne Papers in Language Testing, 15(1), 70-91
Rusinovci, X. (2015). Teaching Writing through Process-Genre Based Approach. US-China Education Review, 5(10), 699-705. Retrieved March 42018 from http://www.davidpublisher.org/Public/uploads/Contribute/564943e786db7.pdf.

Scollon, R. (1997). Contrastive rhetoric, contrastive poetics, or perhaps something else? TESOL Quarterly, 31(2), 352-358

Shaw, S., \& Falvey, P. (2008). The IELTS writing assessment revision project: Towards a revised rating scale. Research Reports No. 1. University of Cambridge ESOL examinations. Retrieved January 18, 2011 from http://www.cambridgeesol.org/assets/pdf/research_reports_01.pdf.

Sheppard, K. (1992). Two feedback types: Do they make a difference?. RELC Journal, 23(1), 103-110.

Simin, S. \& Tavangar, M. (2009). Metadiscourse knowledge and use in Iranian EFL writing. Asian EFL Journal, 11(1), 230-255. Retrieved October 16, 2011 from http:// www.asian-efl-journal.com/March_2009.pdf

Stapa, S. H. \& Abdul-Majid, A. H. (2009). The use of first language in developing ideas in second language writing. The European Journal of Social Sciences, 7(4), 41- 47 .

Sukandi, S. S. (2016). Students' Personal "Colors" In Self-Evaluation Essays As The Post-Process Pedagogy In Teaching Writing (A Descriptive Study On EFL Composition Learning Practice In Indonesia). Proceedings of ISELT FBS Universitas Negeri Padang, 4(2), 361-373. Retrieved March 42018 from http://ejournal.unp.ac.id/ index.php/selt/article/view/6997/5531.

Swaffar, J., Romano, S., Arens, K. \& Markley, P. (Eds.) (1998). Language learning on line: Research and pedagogy in the ESL and L2 computer classroom. Austin, TX: Labyrinth Publications.

Tan, B. H. (2011). Innovative writing centers and online writing labs outside North America. Asian EFL Journal, 13 (2), 391-418. Retrieved September 5, 2011 from http://www.asian-efl-journal.com/PDF/June_2011.pdf

Thompkins, F. 1990. Teaching Writing: Balancing process and product. USA: Merrit Publishing Company.

Vann, R. J. (1980) Oral and written syntactic relationships in second language learning. In C.A. Yorio., K. Perkins. And J. Schachter (Eds.), On TESOL 79: The learner in focus (pp. 322-329). Washington, D.C: Teachers of English to Speakers of Other Languages.

Vaughan, C. (1991). Holistic assessment: What goes on in the raters' mind? In L. Hamp-Lyons (Ed.), Assessing second language writing in academic contexts, (pp. 111126). Norwood, NJ: Ablex Publication Corporation.

Warshauer, M., \& Ware, P. (2006). Automated writing evaluation: defining the classroom research agenda. Language Teaching Research, 10(2), 157-180.

Weigle, S. C. (2002). Assessing writing. Cambridge, UK: Cambridge University Press.

Weir, C. (1990). Communicative language testing. NJ: Prentice Hall Regents.

White, R. and Arndt, V. (1991). Process Writing. Essex: Addison Wesley Longman Ltd. 
Yavuz, D. \& Genc, A.B. (1998). Flexibility of setting up a writing unit at YADIM, Unpublished Action Research Study. Çukurova University, Adana, Turkey.

Yavuz-Erkan, D. \& Ifflazoğlu-Saban, A. (2011). Writing performance relative to writing apprehension, self-efficacy in writing, and attitudes towards writing: A correlational study in Turkish tertiary-level EFL. Asian EFL Jour- nal, 13(1), 164-192. Retrieved September 5, 2011 from http://www.asian-efl-journal.com/PDF/March-2011.pdf Ying, H. (2000). The origin of contrastive rhetoric revisited. International Journal of Applied Linguistics, 10(2), 259-268.

Zamel, V. (1997). Toward a Model of Transculturation. TESOL Quarterly 31, 341-352. 